\title{
Nitrate Accumulation, Productivity and Photosynthesis of Temperate Butter Head Lettuce under Different Nitrate Availabilities and Growth Irradiances
}

\author{
J. He ${ }^{*}$, L. Cheok and L. Qin \\ Natural Sciences and Science Education Academic Group, National Institute of Education, Nanyang Technological \\ University, 1 Nanyang Walk, 637616 Singapore
}

\begin{abstract}
Under low growth-irradiance and/or excessive nitrogen $(\mathrm{N})$ fertilization, the roots of leafy vegetables could take up nitrate $\left(\mathrm{NO}_{3}{ }^{-}\right)$faster than the plant can convert it to organic nitrogen compounds. $\mathrm{NO}_{3}{ }^{-}$is suspected to have carcinogenic effect in human when eaten in high quantity. In this study, lettuce plants were first grown in an aeroponics system with full nutrients (full $\mathrm{NO}_{3}{ }^{-}$) under full sunlight. Six weeks after transplanting, plants were subjected to 7 days of full sunlight and shade with full, $1 / 2$ and $0 \mathrm{NO}_{3}^{-}$respectively. Shoot $\mathrm{NO}_{3}{ }^{-}$concentration was higher under shade than under full sunlight regardless of $\mathrm{NO}_{3}{ }^{-}$availability after 7 days of treatments. The higher shoot $\mathrm{NO}_{3}{ }^{-}$concentration of shade plants was derived from the high $\mathrm{NO}_{3}{ }^{-}$accumulated in their roots during the 6 weeks of growth prior to treatments. There were no significant differences in $\mathrm{NO}_{3}{ }^{-}$concentrations of shoot and root after re-exposing all plants to full sunlight and full $\mathrm{NO}_{3}{ }^{-}$for another 7 days. Total shoot reduced $\mathrm{N}$ concentrations were similar among all plants regardless of treatments. These results indicate that reduction or withdrawing $\mathrm{NO}_{3}{ }^{-}$from nutrient solution did not affect $\mathrm{N}$ metabolism. Low productivity and photosynthesis under shade condition did not result from $\mathrm{NO}_{3}{ }^{-}$availability but they were directly caused by low growth irradiance. Thus, to prevent high accumulation of $\mathrm{NO}_{3}{ }^{-}$in the shoot, it may be a good practice to withdraw $\mathrm{NO}_{3}{ }^{-}$from nutrient solution during cloudy days or to extend the plant growth period a few more days under full sunlight before harvest.
\end{abstract}

Keywords: Growth irradiance, nitrate accumulation, photosynthesis, productivity.

\section{INTRODUCTION}

Vegetables that are capable of accumulating large amounts of $\mathrm{NO}_{3}^{-}$include lettuce, spinach, cabbage, celery and Chinese broccoli [1]. $\mathrm{NO}_{3}{ }^{-}$is present in most food at low concentration. But green leafy vegetables contain higher concentration of $\mathrm{NO}_{3}^{-}$than other foods. In general, $\mathrm{NO}_{3}^{-}$is considered to be of low toxicity but when converted to $\mathrm{NO}_{2}^{-}$, it interacts with haemoglobin and affects the oxygen transport, leading to a condition known as methaemoglobin [2].

Plants normally take up $\mathrm{N}$ from the soil in the form of $\mathrm{NO}_{3}^{-}$, regardless of the form of $\mathrm{N}$ fertilizer applied. However, little $\mathrm{NO}_{3}{ }^{-}$accumulates in plants, when growth is normal, because the plant stems and leaves rapidly convert $\mathrm{NO}_{3}{ }^{-}$to amino acids and protein. Different environmental factors such as light intensity affect the concentration of $\mathrm{NO}_{3}{ }^{-}$in different vegetables. For instance, under low growth irradiance (cloudy days or haze), this balance can be disrupted so that the roots will take up $\mathrm{NO}_{3}{ }^{-}$faster than the plant can convert the $\mathrm{NO}_{3}{ }^{-}$to protein. $\mathrm{NO}_{3}^{-}$accumulation is also dependent on the amount of $\mathrm{N}$-fertilizer and time of application [2]. In countries such as those that experience the four seasons, $\mathrm{NO}_{3}^{-}$levels in plants vary according to the seasons as the amount of $\mathrm{NO}_{3}^{-}$accumulated in the plant tissues is closely related to the nitrate reductase (NR) activity that has been shown to be modulated by light intensity [3-5].

*Address correspondence to this author at the Natural Sciences and Science Education Academic Group, National Institute of Education, Nanyang Technological University, 1 Nanyang Walk, 637616 Singapore; Tel: 6567903817; Fax: 65-68969432; E-mail: jie.he@nie.edu.sg
With regards to the $\mathrm{NO}_{3}{ }^{-}$content, the European Union established the maximum level for lettuce produced in open field as $2.5-4.0 \mathrm{mg} \mathrm{g}^{-1}$ fresh weight (FW) for the summer and winter seasons. For lettuce grown in the greenhouse, it is $3.5-4.5 \mathrm{mg} \mathrm{g}^{-1} \mathrm{FW}$ [6]. Lettuce is the most popular amongst the salad vegetable crops. Both leafy and head types of lettuce are grown at the cool temperatures. We have successfully grown these two types of temperate lettuce in our tropical greenhouse by cooling their roots only [7-9]. He et al., [10] have shown that under natural tropical conditions in Singapore, aeroponically grown Chinese broccoli (Brassica alboglabra) subjected to low light had the highest $\mathrm{NO}_{3}{ }^{-}$ accumulation in the petioles with lower accumulation in the leaves. However, there is little information on how growth irradiance and $\mathrm{NO}_{3}^{-}$application influence the accumulation of $\mathrm{NO}_{3}{ }^{-}$in the shoot of lettuce grown in the tropics. This project aims to study shoot $\mathrm{NO}_{3}{ }^{-}$accumulation in lettuce by growing them under full sunlight and shade (simulating cloudy or haze weather) and they were supplied with different concentrations of $\mathrm{NO}_{3}{ }^{-}$under each growth irradiance at the later growth stage. Effects of growth irradiance and $\mathrm{NO}_{3}{ }^{-}$ availability on the harvest yield and photosynthesis were used to evaluate whether manipulation of growth irradiance and $\mathrm{NO}_{3}{ }^{-}$affects the physiology and productivity.

\section{MATERIALS AND METHODS}

\section{Plant Culture}

A temperate vegetable, $L$. sativa $\mathrm{cv}$. Nanda (butterhead lettuce) was used. Germinated seedlings were transplanted to 
an aeroponics system in the greenhouse. The roots of the plants were maintained at $25^{\circ} \mathrm{C}$ within sealed trough while aerial parts were exposed to the diurnal fluctuating ambient temperature $\left(28^{\circ} \mathrm{C}-40^{\circ} \mathrm{C}\right)$ under full sunlight. The PPFD of sunny days under full sunlight inside the greenhouse was about $800 \mu \mathrm{mol} \mathrm{m} \mathrm{m}^{-2}$. The nutrient solution used to culture plants was based on full strength Netherlands Standard Composition. At full strength, the conductivity of the nutrient solution measured $2.2 \mathrm{mS}$ and $\mathrm{pH} 6 \pm 0.5$. The composition of full strength nutrient solution in $\mathrm{ppm}$ was: $\mathrm{K}_{2} \mathrm{HPO}_{4}, 187 ; \mathrm{Ca}\left(\mathrm{NO}_{3}\right)_{2} .4 \mathrm{H}_{2} \mathrm{O}, 1237 ; \mathrm{MgSO}_{4} .7 \mathrm{H}_{2} \mathrm{O}, 609$; $\mathrm{K}_{2} \mathrm{SO}_{4}, 252 ; \mathrm{KNO}_{3}, 293$; FeEDTA, 20.52; $\mathrm{ZnSO}_{4} .7 \mathrm{H}_{2} \mathrm{O}$, $0.06 ; \mathrm{CuSO}_{4} .5 \mathrm{H}_{2} \mathrm{O}, 0.06 ; \mathrm{H}_{3} \mathrm{BO}_{3}, 0.59 ; \mathrm{MnSO}_{4} . \mathrm{H}_{2} \mathrm{O}, 0.73$; $\left(\mathrm{NH}_{4}\right)_{6} \mathrm{Mo}_{7} \mathrm{O}_{24} .4 \mathrm{H}_{2} \mathrm{O}, 0.75$. Six weeks after transplanting, plants were subjected to six different treatments of growth irradiance and supplied with $\mathrm{NO}_{3}{ }^{-}$described below.

\section{Different $\mathrm{NO}_{3}{ }^{-}$Treatments under Different Growth Irradiances}

Before the treatments, five plants were sampled. The shoot and root FW were recorded. The remaining plants were separated into 6 batches and were grown for further 7 days under two different levels of growth irradiances and supplied with three different concentrations of $\mathrm{NO}_{3}{ }^{-}$. The six different treatments were 1) full sunlight and full $\mathrm{NO}_{3}{ }^{-}$ (188.75 ppm N), 2) full sunlight and $1 / 2 \mathrm{NO}_{3}{ }^{-}(94.38 \mathrm{ppm} \mathrm{N})$, 3) full sunlight and $\left.0 \mathrm{NO}_{3}{ }^{-}(0 \mathrm{ppm} \mathrm{N}), 4\right)$ shade (under two layers of black netting) and full $\mathrm{NO}_{3}{ }^{-}, 5$ ) shade and $1 / 2 \mathrm{NO}_{3}$ and 6) shade and $0 \mathrm{NO}_{3}{ }^{-}$.

The maximal PPFD were $800 \mu \mathrm{mol} \mathrm{m}^{-2} \mathrm{~s}^{-1}$ and $200 \mu \mathrm{mol}$ $\mathrm{m}^{-2} \mathrm{~s}^{-1}$, respectively, under full sunlight and shading on sunny days. Following the 7-day of different growth irradiance and $\mathrm{NO}_{3}{ }^{-}$availability treatments, all plants were reexposed to another 7-day of full sunlight by removing the nettings of shade plants. Treatments with $1 / 2 \mathrm{NO}_{3}{ }^{-}$and $0 \mathrm{NO}_{3}{ }^{-}$ were also changed to full $\mathrm{NO}_{3}{ }^{-}$concentration, that was, all plants were grown under full light and full $\mathrm{NO}_{3}{ }^{-}$.

\section{Measurement of $\mathrm{NO}_{3}{ }^{-}$}

Dried plant tissue was ground with deionised water and then incubated at $37{ }^{\circ} \mathrm{C}$ for $2 \mathrm{~h}$. Sample turbidity was removed by filtration through a $0.45 \mu \mathrm{m}$ pore diameter membrane filter prior to analysis. The $\mathrm{NO}_{3}{ }^{-}$was determined using a Flow Injection Analyser (Model QuikChem 8000, Lachat Instruments Inc, Milwaukee, WI, USA) by catalytically reducing $\mathrm{NO}_{3}{ }^{-}$to $\mathrm{NO}_{2}{ }^{-}$by passage of the sample through a copperized cadmium column. The $\mathrm{NO}_{2}{ }^{-}$was then determined by diazotizing with sulfanilamide followed by coupling with N-(1-naphthyl)ethylenediamine dihydrochloride. The resulting water soluble dye had a magenta color which was read at $520 \mathrm{~nm}$.

\section{Measurement of Total Reduced N Concentration}

Total reduced $\mathrm{N}$ content was determined by Kjeldahl digestion of dried samples in concentrated sulphuric acid [11]. The samples were dried in an oven (4 days set at 80 ${ }^{\circ} \mathrm{C}$ ), their weights recorded then they were placed into a digestion tube with a Kjeldahl tablet and $5 \mathrm{ml}$ of concentrated sulphuric acid. The mixture was then digested (about 90 minutes) until clear. After the digestion was completed, the mixture was allowed to cool for 30 minutes and the reduced $\mathrm{N}$ content was determined by a Kjeltec auto 1030 analyser. The reduced $\mathrm{N}$ content $\left(\mathrm{mg} \mathrm{g}^{-1}\right)$ present in the sample was quantified through titration, and triplicate results were obtained for each treatment.

\section{Measurement of Shoot and Root FW}

After removing the entire plant from the trough during the harvesting time, the plant was separated into shoot and root respectively. The shoot and root FW were weighed separately.

\section{Measurement of Photosynthetic $\mathrm{CO}_{2}$ Assimilation, $A$ and Stomatal Conductance, $g_{\text {s }}$}

$A$ and $g_{\text {s }}$ were measured on newly expanded leaves (the $6^{\text {th }}$ leaves from the base) between 1000 to $1130 \mathrm{~h}$ with LICOR portable photosynthesis system (LI-6400, bio sciences, U.S.) in the greenhouse from the intact leaves. After the first 7-day of different growth irradiance and $\mathrm{NO}_{3}{ }^{-}$availability treatments, readings were taken with an LED light source which supplied 800 and $200 \mu \mathrm{mol} \mathrm{m} \mathrm{m}^{-2} \mathrm{~s}^{-1}$ of PPFD, which were close to the average maximal growth irradiance on the top of the leaves when plants were grown under full sunlight and shade, respectively, in the greenhouse. After re-exposing all plants to full sunlight and full $\mathrm{NO}_{3}{ }^{-}, A$ and $g_{\mathrm{s}}$ of all plants were measured under $800 \mu \mathrm{mol} \mathrm{m} \mathrm{m}^{-2}$ of PPFD. The light source emitted in the wavelength ranging from 660 to 675 $\mathrm{nm}$. Average ambient $\left[\mathrm{CO}_{2}\right]$ and relative humidity in the greenhouse were $380 \pm 5 \mu \mathrm{mol} \mathrm{mol}^{-1}$ and $75 \%$ respectively. Leaf chamber temperature was set according to prevailing ambient conditions $\left(28^{\circ} \mathrm{C}-30^{\circ} \mathrm{C}\right)$.

\section{Statistical Analysis}

A two-way ANOVA was used to test for the effect of $\mathrm{NO}_{3}^{-}$availability and growth irradiance on different parameters. A separate ANOVA was used to discriminate means across all treatments using Tukey's multiple comparison test. All statistical analyses were carried out using MINITAB software (MINITAB, Inc., United States, Release 15, 2007).

\section{RESULTS}

Effects of $\mathrm{NO}_{3}{ }^{-}$Availability and Growth Irradiances on Shoot and $\operatorname{Root} \mathrm{NO}_{3}^{-}$Concentration and Total Leaf Reduced N Content

$\mathrm{NO}_{3}{ }^{-}$concentrations were determined before the treatments. Their values were $12.45 \pm 0.173$ and $29.21 \pm 0.212$ $\mathrm{mg} \mathrm{g}^{-1} \mathrm{DW}$ for shoot and root, respectively. $\mathrm{NO}_{3}^{-}$and total reduced $\mathrm{N}$ concentrations were measured again from both shoot and root after 7 days of different treatments (Fig. 1). The interaction term " $\mathrm{NO}_{3}{ }^{-}$availability $\mathrm{x}$ growth irradiance" of two-way ANOVA was not significant for shoot and root $\mathrm{NO}_{3}{ }^{-}$concentration, and shoot and root total reduced $\mathrm{N}$ concentration, respectively (Table 1, Fig. 1). Separate ANOVA analysis shows that shoot $\mathrm{NO}_{3}{ }^{-}$concentration was much lower in plants under full sunlight than under shade regardless of $\mathrm{NO}_{3}{ }^{-}$availability. For plants grown under shade, they had the highest shoot $\mathrm{NO}_{3}{ }^{-}$concentration when they were supplied with full $\mathrm{NO}_{3}{ }^{-}$followed by those with $1 / 2$ $\mathrm{NO}_{3}{ }^{-}$and the lowest shoot $\mathrm{NO}_{3}{ }^{-}$concentration was found in 

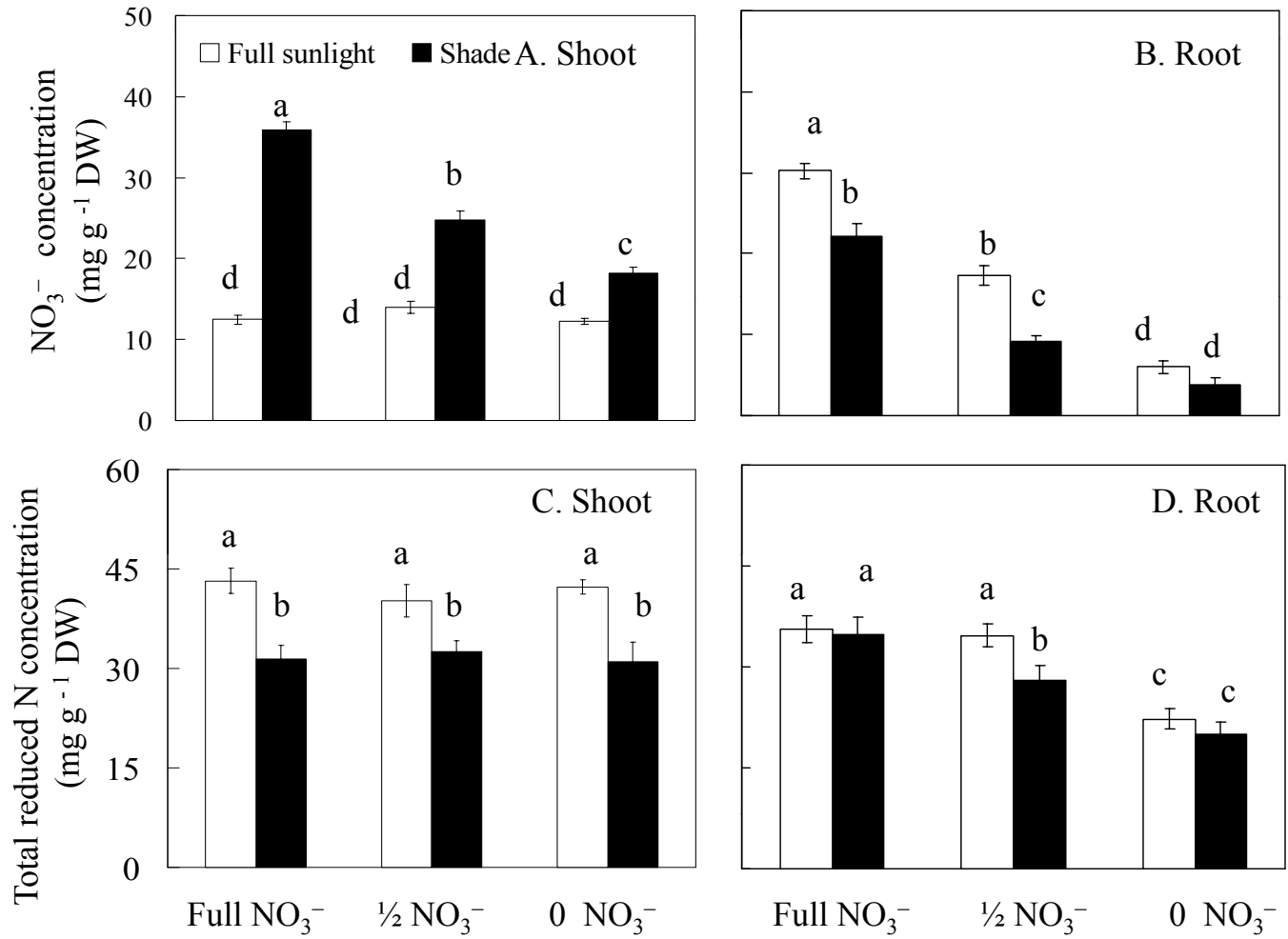

Fig. (1). $\mathrm{NO}_{3}{ }^{-}(\mathbf{A}, \mathbf{B})$ and total reduced $\mathrm{N}$ content $(\mathbf{C}, \mathbf{D})$ of $L$. sativa $\mathrm{cv}$. Nanda after subjecting to two different growth irradiances and $\mathrm{NO}_{3}{ }^{-}$ availabilities for 7 days. Each value is the mean of 5 different plants. Vertical bars represent the standard errors. Means with different letters above the bars are statistically different $(p<0.001)$ as determined by Tukey's multiple comparison test.

plants without $\mathrm{NO}_{3}{ }^{-}$for 7 days (Fig. 1A,$p<0.001$ ). However, there were no significant differences in shoot $\mathrm{NO}_{3}^{-}$ concentration when plants grown under full sunlight regardless of $\mathrm{NO}_{3}^{-}$availability. Oppositely, root $\mathrm{NO}_{3}^{-}$concentration was significantly higher in plants grown under full sunlight than under shade when full or $1 / 2 \mathrm{NO}_{3}{ }^{-}$were supplied to them (Fig. 1B, $p<0.001$ ). Plants grown under both full sunlight and shade had significantly higher root $\mathrm{NO}_{3}{ }^{-}$ concentration when supplied with full $\mathrm{NO}_{3}^{-}$than with $1 / 2$ $\mathrm{NO}_{3}{ }^{-}$and those with $0 \mathrm{NO}_{3}{ }^{-}$(Fig. 1B, $p<0.001$ ). Total shoot reduced $\mathrm{N}$ concentrations were significantly higher in plants grown under full sunlight than under shade (Fig. 1C, $p<$ 0.001 ). However, there were no significant differences in shoot total reduced $\mathrm{N}$ among the different $\mathrm{NO}_{3}{ }^{-}$treatments for plants grown under both full sunlight and shade (Fig. 1C, $p<0.001)$. Plants grown under full and $1 / 2 \mathrm{NO}_{3}{ }^{-}(p>0.05)$ had similar level of root total reduced $\mathrm{N}$ and they were significantly higher than those of plants without $\mathrm{NO}_{3}{ }^{-}$for 7 days regardless of growth irradiances (Fig. 1D, $p<0.001$ ). After 7 days re-exposing to full sunlight and full $\mathrm{NO}_{3}{ }^{-}, \mathrm{NO}_{3}{ }^{-}$ and total reduced $\mathrm{N}$ concentrations were also measured from both shoot and root (Fig. 2). The interaction term " $\mathrm{NO}_{3}{ }^{-}$ availability x growth irradiance" of two-way ANOVA for shoot and root $\mathrm{NO}_{3}^{-}$concentrations, and shoot and root total reduced $\mathrm{N}$ concentrations were respectively, not significant (Table 1, Fig. 2). Separate ANOVA analysis shows that grown under full sunlight and full $\mathrm{NO}_{3}{ }^{-}$, all plants had similar levels of shoot or root $\mathrm{NO}_{3}{ }^{-}$concentrations (Figs. 2A, 2B, $p$ $>0.05$ ), and shoot or root total reduced $\mathrm{N}$ concentrations (Figs. 2C, 2D, $p>0.05$ ) regardless of previous treatments.
Table 1. Two way Analysis of Variance of Physiological Variables, with $P$ Values Presented for their Interaction

\begin{tabular}{|c|c|}
\hline Figures & $\begin{array}{l}\mathrm{NO}_{3}{ }^{-} \text {availability } \mathrm{x} \\
\text { Growth irradiance }\end{array}$ \\
\hline Shoot $\mathrm{NO}_{3}^{-}$(Fig. 1A) & 0.49 \\
\hline Root $\mathrm{NO}_{3}^{-}$(Fig. 1B) & 0.32 \\
\hline Shoot Total Reduced N (Fig. 1C) & 0.66 \\
\hline Shoot Total Reduced N (Fig. 1D) & 0.45 \\
\hline Shoot $\mathrm{NO}_{3}^{-}$(Fig. 2A) & 0.78 \\
\hline Root $\mathrm{NO}_{3}^{-}$(Fig. 2B) & 0.45 \\
\hline Shoot Total Reduced N (Fig. 2C) & 0.53 \\
\hline Shoot Total Reduced N (Fig. 2D) & 0.72 \\
\hline Shoot FW (Fig. 3A) & 0.53 \\
\hline Root FW (Fig. 3B) & 0.47 \\
\hline Shoot FW (Fig. 4A) & 0.29 \\
\hline Root FW (Fig. 4B) & 0.68 \\
\hline$A$ (Fig. 5A) & 0.51 \\
\hline$g_{s}($ Fig. 5B) & 0.33 \\
\hline$A$ (Fig. 6A) & 0.46 \\
\hline$g_{s}($ Fig. 6B) & 0.27 \\
\hline
\end{tabular}



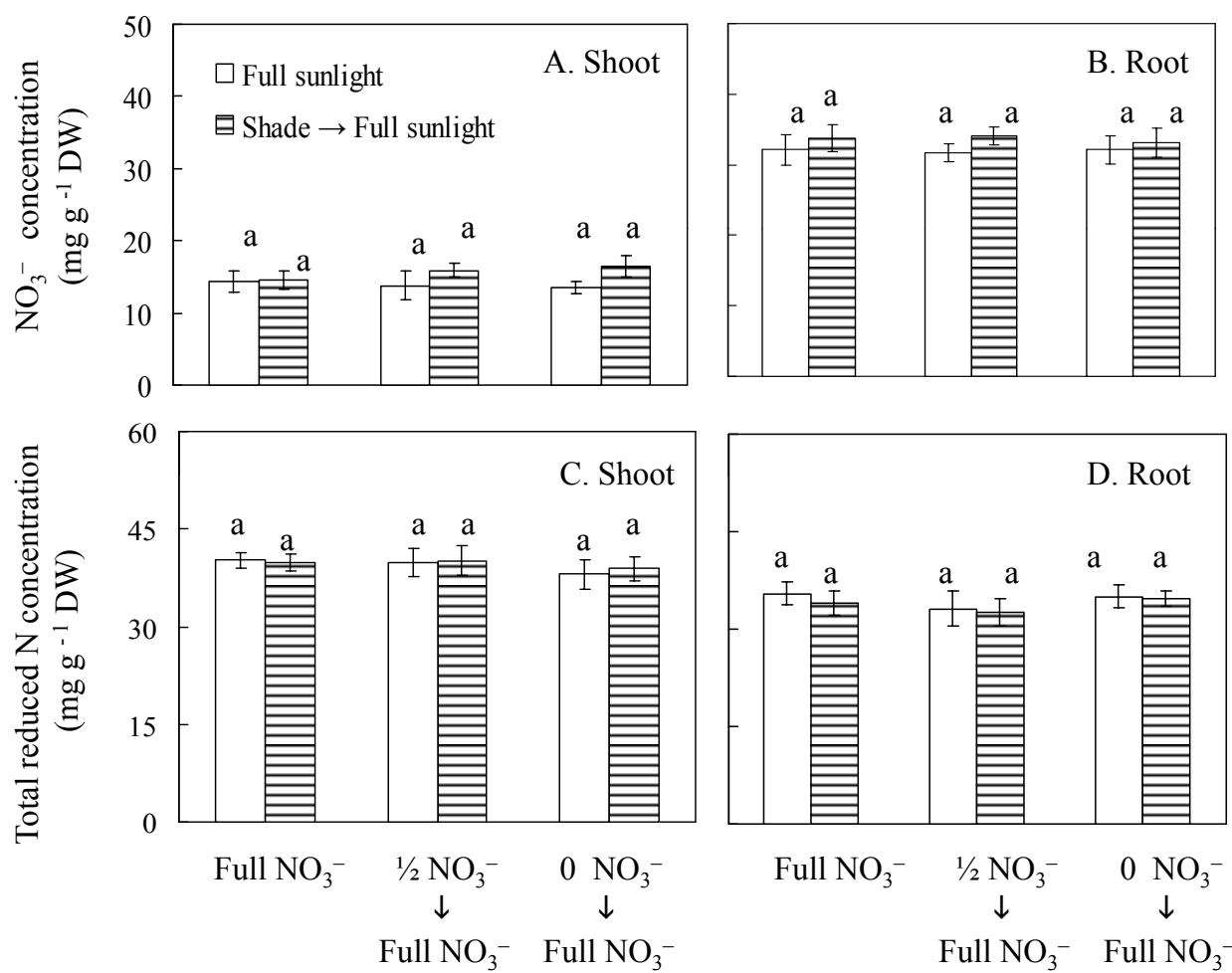

Fig. (2). $\mathrm{NO}_{3}^{-}(\mathbf{A}, \mathbf{B})$ and total reduced $\mathrm{N}$ content $(\mathbf{C}, \mathbf{D})$ of $L$. sativa cv. Nanda after subjecting to two different growth irradiances and $\mathrm{NO}_{3}{ }^{-}$ availabilities for 7 days and followed by re-exposure to full sunlight with full $\mathrm{NO}_{3}{ }^{-}$for another 7 days. Each value is the mean of 5 different plants. Vertical bars represent standard error. Means with different letters above the bars are statistically different $(p<0.001)$ as determined by Tukey's multiple comparison test.

\section{Effects of $\mathrm{NO}_{3}{ }^{-}$Availability and Growth Irradiances on Productivity of Shoot and Root}

Before the lettuce plants were subjected to different treatments, their FW of shoot and roots were $60.47 \pm 3.65 \mathrm{~g}$ and $3.69 \pm 0.28 \mathrm{~g}$, respectively. All plants exhibited increased shoot FW (Fig. 3A) and root FW (Fig. 3B) after a further 7 days of growth under different condition. By the end of the treatments, the interaction term " $\mathrm{NO}_{3}{ }^{-}$availability $x$ growth irradiance" of two-way ANOVA for shoot FW and root FW was respectively, not significant (Table 1, Fig. 3). Separate ANOVA analysis shows that shoot FW and root FW were significantly higher in plants under full sunlight than under shade regardless of $\mathrm{NO}_{3}{ }^{-}$availability (Figs. 3A, 3B, $p<0.001)$. Compared to plants grown under full sunlight and full $\mathrm{NO}_{3}{ }^{-}$, shoot $\mathrm{FW}$ of all other plants were significant lower $(p<0.001)$ (Fig. 3A). When grown under full sunlight with full $\mathrm{NO}_{3}{ }^{-}$, plants had the highest shoot $\mathrm{FW}$ followed by those with $1 / 2 \mathrm{NO}_{3}{ }^{-}$, and the lowest shoot $\mathrm{FW}$ was recorded in plants grown without $\mathrm{NO}_{3}^{-}$for 7 days. However, the higher root $\mathrm{FW}$ was found in plants grown under full sunlight with $0 \mathrm{NO}_{3}{ }^{-}$. There were no significant differences in shoot $\mathrm{FW}$ or root $\mathrm{FW}$ among the different $\mathrm{NO}_{3}{ }^{-}$treatments when plants were grown under shade (Figs. 3A, 3B). After re-exposing all plants to full sunlight and full $\mathrm{NO}_{3}{ }^{-}$for another 7 days, all plants continued to growth and had increased shoot FW (Fig. 4). The interaction term " $\mathrm{NO}_{3}{ }^{-}$ availability $\mathrm{x}$ growth irradiance" of two-way ANOVA for shoot FW and root FW was respectively, not significant (Table 1, Fig. 4A). Separate ANOVA analysis shows that
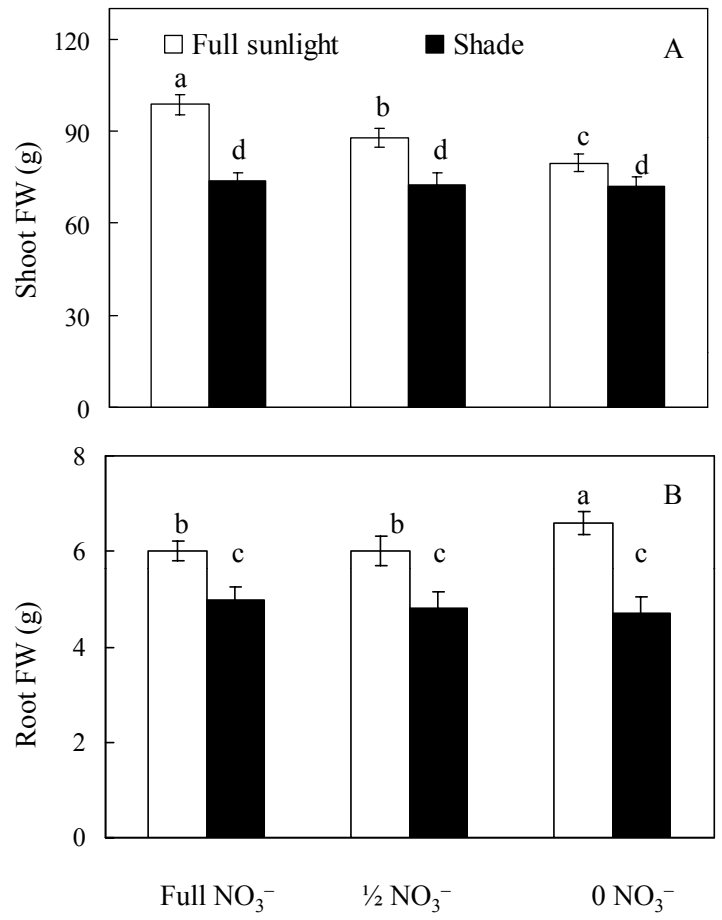

Fig. (3). Shoot FW (A) and root FW (B) of L. sativa cv. Nanda after subjecting to two different growth irradiances and $\mathrm{NO}_{3}{ }^{-}$ availabilities for 7 days. Each value is the mean of 5 different plants. Vertical bars represent the standard errors. Means with different letters above the bars are statistically different $(p<0.001)$ as determined by Tukey's multiple comparison test. 
those plants remained under full sunlight and full $\mathrm{NO}_{3}{ }^{-}$for the entire 14 days of treatment had the higher shoot FW than all other plants (Fig. 4A, $p<0.001$ ), which had no significant differences in their shoot FW regardless of their different previous treatments (Fig. 4A, $p>0.05$ ). After a further 7 days of growth under full sunlight and full $\mathrm{NO}_{3}{ }^{-}$, the average percentages of increment for shoot FW were $10 \%$ and $22 \%$ for plants grown previously under full sunlight and shade respectively. Not only shoot but also roots showed the increase in their growth after another 7 days of re-exposing to full sunlight and full $\mathrm{NO}_{3}^{-}$(Fig. 4B). Root $\mathrm{FW}$ was significantly higher in plants previously grown under full sunlight than in plants previously grown under shade (Fig. 4B, $p<0.001)$. However, there was no significant difference in root $\mathrm{FW}$ among the plants previously treated with different $\mathrm{NO}_{3}{ }^{-}$availabilities after re-exposing to full $\mathrm{NO}_{3}{ }^{-}$for 7 day under the same growth irradiance (Fig. 4B, $p>0.05$ ). There were much lower increments in root FW for all plants compared to those shoot $\mathrm{FW}$ after 7 days of re-exposing to full sunlight and full $\mathrm{NO}_{3}^{-}$. The average percentages of increment were $6 \%$ and $3 \%$ for plants grown under full sunlight and shade respectively.
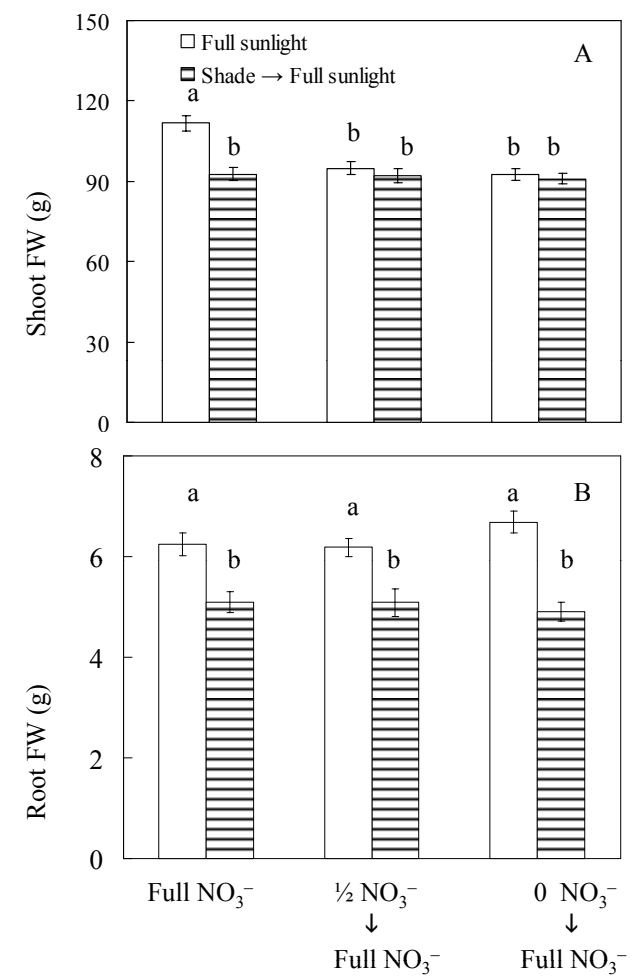

Fig. (4). Shoot FW (A) and root FW (B) of L. sativa cv. Nanda after subjecting to two different growth irradiances and $\mathrm{NO}_{3}$ availabilities for 7 days and followed by re-exposure to full sunlight with full $\mathrm{NO}_{3}^{-}$for another 7 days. Each value is the mean of 5 different plants. Vertical bars represent standard error. Means with different letters above the bars are statistically different $(p<0.001)$ as determined by Tukey's multiple comparison test.

\section{Effects of $\mathrm{NO}_{3}{ }^{-}$Availability and Growth Irradiances on $\mathrm{A}$ and $g_{s}$}

$A$ and $g_{s}$ were measured under 800 and $200 \mu \mathrm{mol} \mathrm{m}^{-2} \mathrm{~s}^{-1}$ of PPFD, which were close to the average maximal growth irradiance on the top of the leaves when plants were grown under full sunlight and shade, respectively, in the greenhouse (Fig. 5). After 7 days of different treatments, the interaction term " $\mathrm{NO}_{3}{ }^{-}$availability $\mathrm{x}$ growth irradiance" of two-way ANOVA was not significant for $A$ and $g_{s}$, respectively (Table 1, Fig. 5). Separate ANOVA analysis shows that $A$ and $g_{s}$ were significantly higher in plants under full sunlight than under shade regardless of $\mathrm{NO}_{3}{ }^{-}$availability (Figs. 5A, 5B, $p$ $<0.001)$. When grown under full sunlight, plants supplied with full $\mathrm{NO}_{3}{ }^{-}$had the highest values of $A$ and $g_{s}$ followed by those with $1 / 2 \mathrm{NO}_{3}^{-}$, and the lowest values of $A$ and $g_{s}$ were recorded in plants with $0 \mathrm{NO}_{3}^{-}$(Figs. 5A, 5B, $p<0.001$ ). These results were similar to those of shoot FW (Fig. 3A), indicating that both full sun light and full $\mathrm{NO}_{3}{ }^{-}$are required for achieving the maximal photosynthetic gas exchange, which was closely related to shoot productivity. Moreover, similar to shoot FW (Fig. 3A), there were no significant differences in $A$ and $g_{s}$ among the different $\mathrm{NO}_{3}^{-}$treatments when plants were grown under shade (Figs. 5A, 5B, $p$ $>0.05$ ). After re-exposing all plants to full sunlight and full $\mathrm{NO}_{3}{ }^{-}$for another 7 days, $A$ and $g_{s}$ were measured under 800 $\mu \mathrm{mol} \mathrm{m} \mathrm{m}^{-2} \mathrm{~s}^{-1}$ of PPFD, which were close to the average maximal growth irradiance on the top of the leaves. The interaction term " $\mathrm{NO}_{3}{ }^{-}$availability $\mathrm{x}$ growth irradiance" of two-way ANOVA for $A$ and $g_{s}$ was respectively, not significant (Table 1, Figs. 6A, 6B). It is surprising to see that all plants had similar levels of $A$ and $g_{s}$ (Figs. 6A, 6B). Separate ANOVA analysis shows that there were no significant differences in $A$ and $g_{s}$ among all plants regardless of previous treatments under different $\mathrm{NO}_{3}{ }^{-}$ availability and growth irradiances (Figs. 6A, 6B, $p>0.05$ ).
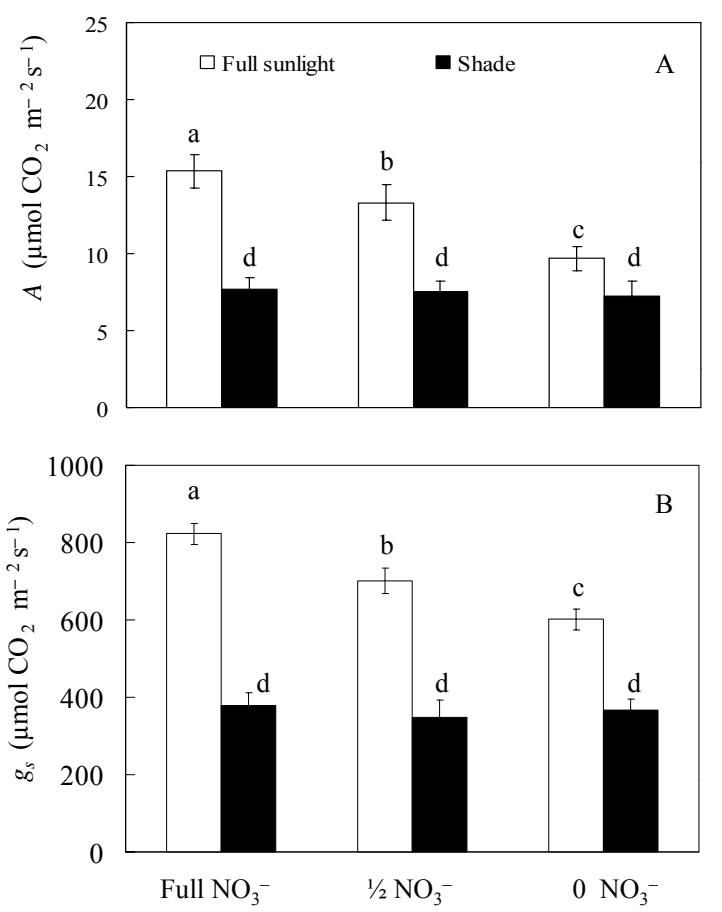

Fig. (5). $A$ (A) and $g_{s}$ (B) of L. sativa cv. Nanda after subjecting to two different growth irradiances and $\mathrm{NO}_{3}{ }^{-}$availabilities for 7 days. $A$ and $g_{s}$ were measured under 800 and $200 \mu \mathrm{mol} \mathrm{m} \mathrm{m}^{-2}$ of PPFD for plants were grown under full sunlight and shade, respectively, in the greenhouse. Each value is the mean of 5 different plants. Vertical bars represent the standard errors. Means with different letters above the bars are statistically different $(p<0.001)$ as determined by Tukey's multiple comparison test. 

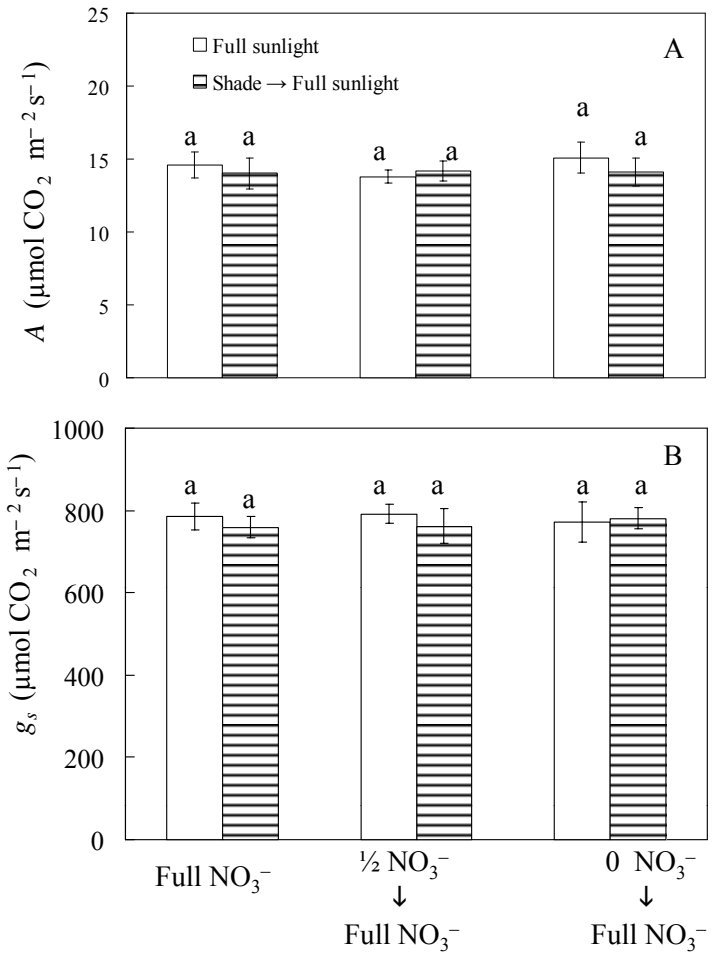

Fig. (6). $A$ (A) and $g_{s}$ (B) of L. sativa cv. Nanda after subjecting to different growth irradiances and $\mathrm{NO}_{3}{ }^{-}$availabilities for 7 days and followed by re-exposure to full sunlight with full $\mathrm{NO}_{3}{ }^{-}$for another 7 days. $A$ and $g_{s}$ were measured under $800 \mu \mathrm{mol} \mathrm{m} \mathrm{m}^{-2} \mathrm{~s}^{-1}$ of PPFD for all plants in the greenhouse each value is the mean of 5 different plants. Vertical bars represent standard error. Means with same letter above the bars are not statistically different $(p>0.05)$ as determined by Tukey's multiple comparison test.

\section{DISCUSSION}

It is well known that light influences the uptake of $\mathrm{NO}_{3}{ }^{-}$ and its assimilation in plants [12-16]. In Singapore, plants are exposed to intermittent days of clear and cloudy (or haze) weather. $\mathrm{NO}_{3}{ }^{-}$concentration of leafy vegetable could be depending on growth irradiances [17, 18]. He and Lim [10] reported that when grown under low light in Singapore, aeroponically grown $B$. alboglabra (cv. Chinese broccoli) in the tropical greenhouse accumulated higher $\mathrm{NO}_{3}{ }^{-}$in their editable petioles and leaves than those of plants grown under high light. Reduced productivity, $A$ and $g_{s}$ were observed in low-light grown plants compared to those of plants grown under higher light. In this study, $\mathrm{NO}_{3}{ }^{-}$accumulation in both shoot and root, productivity and photosynthesis of lettuce plants were studied not only under different growth irradiances but also different levels of $\mathrm{NO}_{3}{ }^{-}$in the nutrient solution.

Aeroponics is a system used for the temperate lettuce cultivation in tropical Singapore by cooling the root-zone only, which could produce homogenous and high-quality vegetables throughout the entire year [7-9]. However, $\mathrm{NO}_{3}{ }^{-}$ used in an aeroponic cultivation may lead to a high $\mathrm{NO}_{3}{ }^{-}$ accumulation in leaves, especially during the cloudy or haze days. In this study, cloudy or haze weather was simulated by shading the lettuce plants for 7 days during the mature growth stage, i.e. 6 weeks after transplanting [19]. Shading caused higher $\mathrm{NO}_{3}{ }^{-}$accumulation in the shoot compared to plants grown under full sunlight. The higher shoot $\mathrm{NO}_{3}{ }^{-}$ concentrations of shade plants were derived from the high $\mathrm{NO}_{3}{ }^{-}$accumulated in their roots during the 6 weeks of growth prior to treatments. $\mathrm{NO}_{3}{ }^{-}$uptake and transport are affected by growth irradiance $[17,18]$. Zhao and Oosterhuis [17] studied the effect of shade (63\% light reduction) on the mineral nutrient status of Gossypium hirsutum plants. They found that an 8-day period of shade increased petiole $\mathrm{NO}_{3}{ }^{-}$ by $145 \%$. Similarly, in the present study, low light did not inhibit the uptake and transport of $\mathrm{NO}_{3}^{-}$. Instead, it enhanced $\mathrm{NO}_{3}{ }^{-}$transport from root to shoot. The increases in shoot $\mathrm{NO}_{3}{ }^{-}$concentration under shade condition may result from several causes, namely, limitation by the availability of reducing power [20,21] or inactivation of NR [22-25]. However, it is interesting to note that plants grown under full sunlight had similar levels of low shoot $\mathrm{NO}_{3}{ }^{-}$concentration regardless of $\mathrm{NO}_{3}{ }^{-}$availability. All plants continued to grow during the 7 days of different treatments. Both full sunlight and full $\mathrm{NO}_{3}^{-}$are required for achieving maximal shoot productivity. These results well agree with that in soilless culture, $\mathrm{NO}_{3}{ }^{-}$is required in the highest amounts by vegetable plants. When grown under full sunlight, $\mathrm{NO}_{3}^{-}$deficiency limits growth and yield of vegetable crops [26,27]. Reducing or removing $\mathrm{NO}_{3}{ }^{-}$source from the nutrient solution under full sunlight may promote root growth and thus decreasing shoot FW as plants may spend more energy to uptake $\mathrm{NO}_{3}{ }^{-}$ from the nutrient solution or to transport $\mathrm{NO}_{3}^{-}$that accumulated excessively in the roots to the shoot [27]. However, $\mathrm{NO}_{3}{ }^{-}$availability had very little impact on shoot and root FW when grown under shade. Since removing $\mathrm{NO}_{3}{ }^{-}$ from the nutrient solution after shading the plants did not cause further decreases in shoot $\mathrm{FW}$, to avoid high accumulation of $\mathrm{NO}_{3}^{-}$in the shoot, it would be a great benefit for both grower and consumer if $\mathrm{NO}_{3}{ }^{-}$would be totally withdrawn during the cloudy or haze days.

$\mathrm{NO}_{3}{ }^{-}$incorporation into biological molecules such as organic $\mathrm{N}$ compounds measured as total reduced $\mathrm{N}$ content in the present study involves the reduction of $\mathrm{NO}_{3}{ }^{-}$to $\mathrm{NO}_{2}{ }^{-}$ mainly via NR [23-25]. Total reduced $\mathrm{N}$ concentration in vegetables depends on the light intensity $[16,28]$ as the regulation of NR is closely coupled to photosynthesis. In the present study, lower $A$ and $g_{s}$ of shade plants were mainly due to lower growth irradiance rather than the total reduced $\mathrm{N}$ as all plants have similar levels of shoot total reduced $\mathrm{N}$. According to Solomonson and Barber [29], as much as $25 \%$ of photosynthetic energy was consumed by the $\mathrm{NO}_{3}{ }^{-}$ assimilation pathway. Total reduced $\mathrm{N}$ content determines the synthesis of amino acids and therefore of proteins and, ultimately, of all cellular components. However, after shading the plants, reducing or withdrawing $\mathrm{NO}_{3}^{-}$from nutrient solution had no impact on shoot and root total reduced $\mathrm{N}$ content, productivity and photosynthesis. These results indicate that low productivity and photosynthesis under shade condition for 7 days did not result from $\mathrm{NO}_{3}{ }^{-}$ availability and $\mathrm{NO}_{3}{ }^{-}$assimilation (thus the total reduced $\mathrm{N}$ ) but they were directly caused by low growth irradiance.

This study also simulated sunny weather following cloudy days by re-exposing all plants to full sunlight as well as full $\mathrm{NO}_{3}{ }^{-}$. All plants had similar low levels of shoot $\mathrm{NO}_{3}{ }^{-}$ but higher level of total reduced $\mathrm{N}$ concentrations of shoot 
and root after 7 days of such treatments. These results further supported that high light stimulated $\mathrm{NR}$ activity and $\mathrm{NO}_{3}{ }^{-}$ assimilation of shoot [22-25], which is closely related to its higher photosynthetic rate as all plants had similar $A$ and $g_{s}$ when measured under $800 \mu \mathrm{mol} \mathrm{m}{ }^{-2} \mathrm{~s}^{-1}$. It is interesting to see that increases in shoot FW were greater in plants previously grown under the shade than those which were remained under full sunlight after 7 days of full sunlight and full $\mathrm{NO}_{3}{ }^{-}$treatments. The higher shoot $\mathrm{FW}$ was due to higher biomass that was partitioned into the shoot rather than roots as the increment of root $\mathrm{FW}$ after exposing to full sunlight and full $\mathrm{NO}_{3}^{-}$was much lower than that of shoot. In our previous studies, it was found that under favorable condition, the growth of lettuce aerial part was increased more than the growth of root, which leads to an increase in the shoot/root ratio [30]. This finding suggests that light is primary factor in partitioning the new assimilates that provide optimal proportions of shoot and root as plant production is driven by photosynthesis [31].

After 7 days of shading with full $\mathrm{NO}_{3}{ }^{-}$, shoot had the highest $\mathrm{NO}_{3}{ }^{-}$concentration about $39.25 \mathrm{mg} \mathrm{g}^{-1} \mathrm{DW}$ or 0.36 $\mathrm{mg} \mathrm{g}{ }^{-1} \mathrm{FW}$. The acceptable level of $\mathrm{NO}_{3}^{-}$for fresh lettuce was 0.791 to $1.017 \mathrm{mg} \mathrm{g}^{-1} \mathrm{FW}$ in Germany and $0.7 \mathrm{mg} \mathrm{g}^{-1}$ FW in China [32]. However, after re-exposing the shaded lettuce plants to full sunlight and full $\mathrm{NO}_{3}{ }^{-}$for 7 days, the highest shoot $\mathrm{NO}_{3}{ }^{-}$concentration declined to about $12.12 \mathrm{mg}$ $\mathrm{g}^{-1} \mathrm{DW}$ or $0.11 \mathrm{mg} \mathrm{g}^{-1} \mathrm{FW}$. Although those plants were previously subjected to shade did not gain the productivity as high as those plants which were grown under full sunlight for the whole life cycle, however, they showed substantial and faster growth after re-exposing them to full sunlight for 7 days following shading. As mentioned earlier, totally withdrawing $\mathrm{NO}_{3}^{-}$from the nutrient solution is a good practice to maintain low shoot $\mathrm{NO}_{3}{ }^{-}$concentration during the cloudy or haze weather. Based on the above calculation, the other good practice is not to harvest the lettuce vegetables immediately after cloudy or haze periods but to expose them for a few more days of full sunlight prior to harvest. This practice will also benefit both the lettuce grower and the consumer as there was more rapid shoot growth with low shoot $\mathrm{NO}_{3}{ }^{-}$concentration for those previously shaded plants after re-exposing to full sunlight and full $\mathrm{NO}_{3}{ }^{-}$for a few days.

\section{CONCLUSION}

Short-term shading the lettuce plants resulted in the highest level of shoot $\mathrm{NO}_{3}{ }^{-}$accumulation when supplied with full $\mathrm{NO}_{3}{ }^{-}$. Reduction of productivity and photosynthesis after shading the plants was caused by low light not $\mathrm{NO}_{3}{ }^{-}$ availability. After re-exposing shaded plants to full sunlight and full $\mathrm{NO}_{3}{ }^{-}$, shoot $\mathrm{NO}_{3}{ }^{-}$concentration decreased to similar low level of those plants grown under full sunlight. Shaded plants showed substantial and faster growth after re-exposing them to full sunlight and full $\mathrm{NO}_{3}^{-}$following shading. To avoid high $\mathrm{NO}_{3}{ }^{-}$accumulation in the editable shoot and at the same time benefiting the growers, recommendations include, 1) not to harvest the vegetable during or immediately after cloudy or haze weather, 2) totally removing $\mathrm{NO}_{3}{ }^{-}$from the nutrient solution during cloud or haze weather and then extend the growth period for another few more days under full sunlight supplied with $\mathrm{NO}_{3}{ }^{-}$before harvest.

\section{ACKNOWLEDGEMENT}

This research was supported by a research grant to RI 7/05 HJ from Academic Research Fund, Ministry of Education, Singapore.

\section{CONFLICT OF INTEREST}

None declared.

\section{REFERENCES}

[1] Dich J, Jrvinen R, Knekt P, Penttil PL. Dietary intakes of nitrate, nitrite and NDMA in the finish mobile clinic health examination survey. Food Add Cont 1996; 13: 541-52.

[2] Guadagnin S, Rath S, Reyes F. Evaluation of the nitrate content in leaf vegetables produced through different agricultural systems. Food Add Cont 2005; 1203-8.

[3] Sušin J, Kmecl V, Gregorčič A. A survey of nitrate and nitrite content of fruit and vegetable grown in Slovenia during 1996-2002. Food Add Cont 2006; 23 : 385-90.

[4] De Cires A, de la Torre A, Delgado B, Lara C. Role of light and $\mathrm{CO}_{2}$ fixation in the control of nitrate-reductase activity in barley leaves. Planta 1993; 190: 277-83.

[5] Ferretti M, Merlo L, Passera C, Ghisi R. Influence of irradiance on enzymes of sulphate and nitrate assimilation pathways in maize leaves. Plant Physiol Biochem 1995; 33: 111-14.

[6] Zhong W, Hu C, Wang, M. Nitrate and nitrite in vegetables from north China: content and intake. Food Add Cont 2002; 19: 1125-9.

[7] He J, Lee SK. Growth and Photosynthetic characteristics of lettuce (Lactuca sativa L.) under fluctuating hot ambient temperatures with the manipulation of cool root-zone temperature. J Plant Physiol 1998; 152: 387-91.

[8] He J, Lee SK. Effects of different root zone temperatures and growth irradiances on three lettuce cultivars (Lactuca sativa L.) grown under tropical aerial condition. I. Photosynthesis and productivity. J Hortic Sci Biotech 1998b; 73: 173-80.

[9] He J, Lee SK, Dodd IC. Limitations to photosynthesis of lettuce grown under tropical conditions: alleviation by root-zone cooling. $\mathrm{J}$ Exp Bot 2001; 52: 1323-30.

[10] He J, Lim LI, Qin L. Accumulation of nitrate in aeroponicall grown Brassica alboglabra (cv. Chinese broccoli) and its physiological basis under different growth irradiances. Acta Hortic 2011 (in press).

[11] Allen SE. Analysis of vegetation and other organic materials. chemical analysis of ecological materials. Blackwell Scientific Publication, Oxford, England 1989; 46-61.

[12] Cheng CL, Acedo GN, Christinsin M, Conkling MA. Sucrose mimics the light induction of Arabidopsis nitrate reductase gene transcription. Proc Natl Acad Sci USA 1992; 89: 1861-4.

[13] Campbell WH. Nitrate reductase structure, function and regulation: bridging the gap between biochemistry and physiology. Ann Rev Plant Physiol Plant Mol Bio 1999; 50: 277-303.

[14] Faure JD, Meyer C, Caboche M. Nitrate assimilation: nitrate and nitrite reductases. In: Nitrogen assimilation by plants, MorotGaudry JF. Ed. Enfield: Science Publishers Inc. 2001; 33-52.

[15] Steingröver EG, Steenhuizen JW, Wanderboon J. Effects of lowlight intensities at night on nitrate accumulation in lettuce grown on a recirculating nutrient solution. J Horti Sci 1993; 41: 13-21.

[16] Makus DJ, Hettiarachchy NS. Nitrogen fertilization and light intensity affects the agronomic. performance and leaf blade oxalate and nutrient concentrations of vegetable amaranth. Subtropical Plant Sci 2001; 53: 27-33.

[17] Zhao D, Oosterhuis D. Cotton responses to shade at different growth stages: Nonstructural carbohydrate composition. Crop Sci 1998; 38: 1196-203.

[18] Aslam M, Travis RL, Rains DW. Diurnal fluctuations of nitrate uptake and in vivo nitrate reductase activity in Pima and Acala cotton. Crop Sci 2001; 41: 372-8.

[19] He J, Tan LP, Lee SK. Root-zone temperature effects on photosynthesis, ${ }^{14} \mathrm{C}$-photoassimilate partitioning and growth of temperate lettuce (Lactuca sativa cv. 'Panama') grown in the tropics. Photosynthetica 2009; 47: 95-103. 
[20] Abrol YP, Sawhney SK, Naik MS. Light and dark assimilation of nitrate in plants. Plant, Cell Environ 1983; 6: 595-9.

[21] Aslam M, Huffaker RC. Dependency of nitrate reduction on soluble carbohydrates in primary leaves of barley under aerobic conditions. Plant Physiol 1984; 75: 623-8.

[22] Riens B, Heldt HW. Decrease of nitrate reductase activity in spinach leaves during a light-dark transition. Plant Physiol 1992; 98: 573-7.

[23] Forde GG. Local and long-range signalling pathways regulating plant responses to nitrate. Ann Rev Plant Biol 2002; 53: 203-4.

[24] Bakken AK, Macduff JH. Diurnal variation in uptake and xylem contents of inorganic and assimilated $\mathrm{N}$ under continuous and interrupted N supply to Phleum pratense and Festuca pratensis. J Exp Bot 2003; 54: 431-44.

[25] Cookson SJ, Williams LE, Miller AJ. Light-dark changes in cytosolic nitrate pools depend on nitrate reductase activity in Arabidopsis leaf cells. Plant Physiol 2005; 138: 1097-105.

[26] Magaña RH, Adamowicz S, Pagès L. Diel changes in nitrogen and carbon resource status and use for growth in young plants of tomato (Solanum lycopersicum). Ann Bot 2009; 103: 1025-37.
[27] He J. Mineral nutrition of aeroponically grown subtropical and temperate crops in the tropics with manipulation of root-zone temperature at different growth irradiances. Plant Stress 2010; 4: $14-30$.

[28] Steingröver EG, Steenhuizen JW, Wanderboon J. Effects of lowlight intensities at night on nitrate accumulation in lettuce grown on a recirculating nutrient solution. J Horti Sci 1993, 41: 13-21.

[29] Solomonson LP, Barber MJ. Assimilatory nitrate reductase: functional properties and regulation. Ann Rev Plant Physiol Plant Mol Bio 1990; 41: 225-53.

[30] He J. Impact of root-zone temperature on photosynthetic efficiency of aeroponically grown temperate and subtropical vegetable crops in the tropics. In: Buchner, TB, Ewingen NR, theory and applications in energy. Biotechnol and Nanotechnol 2009; Chapter 4: 111-44. Nova Science Publishers, Inc., New York.

[31] Loomis MJ, Amthor JS. Yield potential, plant assimilatory capacity and metabolic efficiencies. Crop Sci 1999; 39: 1584-96.

[32] Schwemmer, E. Nitrat in Gemüse. Gemüse 1990; 3: 172-5.

Received: August 30, 2011

Revised: October 26, 2011

Accepted: November 11, 2011

(C) He et al.; Licensee Bentham Open.

This is an open access article licensed under the terms of the Creative Commons Attribution Non-Commercial License (http://creativecommons.org/ licenses/by-nc/3.0/), which permits unrestricted, non-commercial use, distribution and reproduction in any medium, provided the work is properly cited. 